\title{
RETORIKA PERSUASIF DALAM DEBAT CALON PRESIDEN INDONESIA 2019: SEBUAH ANALISIS KOMUNIKASI PERFORMATIF
}

\author{
Meganusa Ludvianto ${ }^{1}$, Wenny Arifani ${ }^{2}$ \\ ${ }^{1}$ Universitas Gadjah Mada, meganusa.pl@gmail.com \\ ${ }^{2}$ Universitas Gadjah Mada, wenny.arifani@gmail.com
}

\begin{abstract}
ABSTRAK
Debat antar calon presiden merupakan rangkaian penting dari upaya menjalankan pemerintahan yang demokratis di Indonesia. Melalui perdebatan yang disiarkan secara langsung, para capres berpeluang untuk menunjukkan kualitas gagasan yang dimiliki, pemahaman atas isu kontemporer, kapasitas berdialog, serta kemampuan mempertahankan argumen. Strategi berbicara di depan umum (public speaking) yang dipilih oleh masing-masing kandidat bisa berpengaruh dalam proses persuasi publik. Studi ini bertujuan untuk membandingkan strategi public speaking para calon presiden dalam rangkaian Pemilihan Umum 2019 di Republik Indonesia. Dengan menggunakan perspektif komunikasi performatif yang dicetuskan oleh Aristoteles, penelitian ini membandingkan aspek ethos, logos dan pathos pada pidato masingmasing calon presiden, Joko Widodo dan Prabowo Subianto, dalam Debat Capres Kedua Pemilu 2019, yang berlangsung pada tanggal 18 Februari 2019. Studi ini menemukan bahwa kedua calon presiden menggunakan strategi komunikasi performatif yang berbeda meskipun berada di ruang debat yang sama. Kedua calon presiden ini menunjukkan pemanfaatan aspek komunikasi performatif secara strategis.
\end{abstract}

Kata kunci: Pemilu, debat calon presiden, public speaking, retorika persuasif.

\begin{abstract}
The debate between presidential candidates is an important series of efforts to run a democratic government. These debates are broadcasted live and the candidates had the opportunity to show the quality of their ideas, understanding of contemporary issues, and the ability to defend arguments. The public speaking strategy opted by each candidate can influence the process of public persuasion. This study aims to compare the public speaking strategies of presidential candidates in the 2019 General Elections in the Republic of Indonesia. Employing Aristotle's classical view of performative communication, this study compared the aspects of ethos, logos and pathos in the speeches of each presidential candidate, Joko Widodo and Prabowo Subianto, in the Second Presidential Election Debate of 2019.This study discovers that the two presidential candidates used different performative communication strategies despite being in the same debate room. Both of these presidential candidates demonstrate the strategic use of aspects of performative communication.
\end{abstract}

Keywords: Elections, presidential candidate debates, public speaking, persuasive rhetorics 


\section{PENDAHULUAN}

Di tahun 2019, Indonesia melaksanakan Pemilihan Presiden secara langsung. Kegiatan yang berlangsung setiap lima tahun ini mempertemukan dua calon presiden: Joko Widodo, petahana yang ingin melanjutkan kepemimpinannya di periode kedua dan Prabowo Subianto, seorang purnawirawan jenderal dan pendiri serta ketua partai Gerindra, salah satu partai kontemporer dengan usia relatif muda dan popularitas tinggi di masyarakat Indonesia. Prabowo merupakan anggota militer yang cukup terpandang. Mempertimbangkan adanya persepsi bahwa personel militer cocok di kursi pimpinan pemerintahan Indonesia (Shibghotulloh, 2019), Prabowo menjadi kandidat yang kuat. Di sisi lain, Joko memiliki keunikan di dalam perpolitikan Indonesia karena ia tidak berasal dari kalangan militer maupun dari keluarga pendiri partai politik. Meskipun demikian, popularitasnya meningkat pesat sebelum ia terpilih menjadi presiden tahun 2014 karena citra yang kuat sebagai 'orang biasa yang dekat dengan rakyat' (Aji \& Dartanto, 2018). Kemenangan Joko pada Pemilu 2014 juga dilihat sebagai sebuah penyegaran di dalam pemerintahan Indonesia yang biasanya dipimpin oleh pensiunan militer (Shibghotulloh, 2019).

Untuk meyakinkan pemilih potensial mereka, masing-masing kandidat wajib berpartisipasi dalam debat presiden yang diselenggarakan oleh Komisi Pemilihan Umum (KPU). Debat ini dilaksanakan di dalam masa kampanye sebanyak lima kali, dan bertujuan untuk mempromosikan program serta mengeksploitasi kelemahan lawannya. Rangkaian debat calon presiden dan wakil presiden ini disiarkan secara langsung melalui stasiun televisi nasional dan via internet untuk menjangkau khalayak yang lebih luas. Secara prinsip demokrasi, debat merupakan perwujudan dari dialektika kebebasan berpendapat. Melalui berdebat, pihak yang terlibat bisa saling memberi kritik secara konstruktif sehingga dapat memperkaya kualitas diskursus yang sedang diperdebatkan. Dari segi praktis, karisma, karakter dan kualitas kecerdasan kandidat menjadi pertimbangan yang cukup krusial bagi konstituen. Debat memberikan ruang bagi para kandidat untuk mendemonstrasikan kapasitas kognitif, relevansi pengalaman kepemimpinan serta karakter mereka secara langsung, yang mana menjadi salah satu faktor penting bagi pemilih potensial dalam memberikan suara mereka di Pemilihan Umum nantinya.

Mempertimbangkan perbedaan karakter dari kedua calon presiden pada Pemilihan Umum 2019 serta bagaimana pidato dalam debat capres berpengaruh kepada kualitas persuasi politis terhadap publik, peneliti tertarik untuk membandingkan strategi public speaking yang digunakan oleh Joko Widodo dan Prabowo Subianto pada debat presiden kedua yang disiarkan pada 18 Februari 2019, dan didokumentasikan pada tautan

YouTube: https://www.youtube.com/watch? $\mathrm{v}=\mathrm{Ck} 4 \mathrm{gJy}$ O4GMc. Secara khusus, peneliti menggunakan kerangka kerja retorika persuasi dalam komunikasi performatif yang dicetuskan oleh Aristoteles, yang terdiri dari ethos, pathos dan logos. Menurut Wrobel (2015) dan Varpio (2018), istilah ethos merujuk pada kredibilitas pembicara, pathos berasosiasi dengan daya tarik pembicara terhadap emosi penonton, dan logos berarti aspek logika atau substansi dari yang disampaikan pembicara. Sudut pandang ini jarang dipakai dalam usaha memahami debat capres; umumnya perspektif yang diambil adalah sudut pandang linguistik dan turunannya. Misalnya, Collins \& Jisum (2019) yang membangun argumen tentang bagaimana bahasa yang digunakan dalam sebuah perdebatan merepresentasikan berbagai dimensi filsafat yang mendasari pemikiran pembicara. Di sisi lain, ilmuwan komunikasi lebih cenderung tertarik pada fenomena pelaksanaan pemilu secara umum, misalnya dari sudut pandang komunikasi strategis di ranah digital (Leliana \& Agusta, 2019; Sandra, 2013) atau interaksi publik dengan sistem media yang cenderung bias pada aspirasi politik tertentu (Simarmata, 2017). Masih sedikit yang menilai komunikasi performatif, sebagai irisan antara dimensi linguistik dan 
komunikasi, sebagai aspek yang krusial dalam memahami debat calon presiden dalam keseluruhan usaha edukasi politik partisipatif di Indonesia. Oleh karena itu, diharapkan bahwa hasil studi ini dapat berkontribusi dalam bidang keilmuan komunikasi politik dari sudut pandang yang baru.

Struktur tulisan ini adalah sebagai berikut: pertama, peneliti memaparkan deskripsi konteks mengenai tema ini, didukung dengan alasan untuk memilih subjek studi tersebut. Kedua, tulisan ini membangun kerangka teori dengan meninjau literatur terkait peran retorika dalam komunikasi performatif. Menggunakan kerangka teori tersebut, peneliti melakukan analisis terhadap aspek retorika persuasif pada debat presiden kedua. Analisis tersebut bertujuan untuk mengamati bagaimana para kandidat memperhitungkan aspek public speaking di dalam performa mereka saat berdebat. Esai ini lalu ditutup dengan kesimpulan dan pembahasan keterbatasan dalam pelaksanaan studi.

\section{KAJIAN LITERATUR}

\section{Retorika Persuasi Aristoteles}

Aristoteles mengidentifikasi tiga aspek yang krusial dalam proses persuasi: Logos, Ethos dan Pathos (Varpio, 2018). Meskipun prinsip ini dicetuskan ratusan tahun yang lalu, banyak pakar komunikasi performatif yang berpendapat bahwa ketiga aspek ini tetap relevan dalam diskursus berbicara di depan publik yang kontemporer. Memang masih terdapat perdebatan mengenai efektivitas dan proporsi ideal masing-masing aspek dalam penyampaian pesan dalam konteks yang berbeda, akan tetapi secara umum praktek komunikasi massa dalam berbagai bentuk serta public speaking masih mengadopsi ketiga prinsip dasar tersebut.

Aspek pertama adalah logos, yang merujuk pada penyampaian isi pesan secara logis, runtut dan terstruktur. 'Pesan', yang bagi Wróbel (2015) didefinisikan sebagai 'argumen', harus mengacu pada kerangka logika yang berkesinambungan karena bertujuan untuk memenuhi kebutuhan rasional dan kognitif audiens. Audiens tidak dianggap sebagai penerima pesan yang pasif; mereka cenderung menyaring pesan yang mereka terima secara kritis sesuai dengan pengalaman dan referensi kognitif mereka. Audiens akan berusaha untuk menerima pesan secara kritis dan skeptis, membedah pesan secara keseluruhan sebelum berkesimpulan bahwa pesan tersebut layak diterima (Varpio, 2018).

Bagaimanapun, proses penyampaian pesan tidak bisa dilihat secara elementer; kita tidak bisa menganggap bahwa satu aspek lebih unggul daripada yang lain. Pesan cenderung diterima sebagai satu paket antara pesan dan media penyampaian, sehingga Scarantino (2008) menekankan bahwa proses penyampaian pesan yang hanya mengandalkan pemenuhan kebutuhan logis semata akan mengurangi efektifitas presentasi pesan secara signifikan. Sebagian besar orang mengalami kesulitan untuk memproses informasi yang disampaikan dengan bahasa faktual yang 'dingin', sehingga kecenderungan untuk terlalu mengandalkan pendekatan logos dalam sebuah komunikasi performatif justru akan kontraproduktif. Hal ini disebabkan karena manusia cenderung kesulitan untuk menilai sebuah informasi secara logika saja, karena di dalam proses penerimaan pesan, aspek emosional juga memiliki pengaruh yang cukup kuat (Scarantino, 2008).

Aspek kedua dalam kerangka komunikasi performatif Aristoteles, menurut Wróbel (2015), adalah pathos. Pathos merujuk pada usaha pembicara untuk berinteraksi dengan sisi emosional dari audiens. Baccarani dan Bonfanti (2015) menyatakan bahwa fungsi public speaking adalah untuk membujuk hadirin untuk berpikir dan bertindak dengan cara tertentu (to persuade), dan bagaimana cara audiens menyikapi pesan tersebut secara emosional menjadi faktor yang penting. Sebagai contoh, dalam sebuah kampanye politik, pembicara menyampaikan pidatonya tidak hanya untuk menyampaikan informasi, tetapi juga untuk membuat konstituennya percaya terhadap suatu gagasan, 
mendukung (atau menolak) sebuah posisi politis atau bahkan mendorong perubahan ke arah tertentu (Baccarani \& Bonfanti, 2015). Dalam situasi seperti ini, pembicara perlu menarik empati dan simpati audiens. Akan tetapi, Varpio (2018) mengingatkan bahwa seorang public speaker perlu berhatihati dalam mengelola aspek pathos karena pemanfaatan yang berlebihan justru akan kontra-produktif terhadap kekuatan persuasi pesan.

Aspek terakhir yang dianggap fundamental oleh Aristoteles adalah ethos, atau karakter dari pembicara. Dimensi ini unik karena terbentuk dari dua arah: kredibilitas dan karakter yang memang dirancang secara sengaja oleh pembicara, dan bagaimana publik menilai karakter tersebut. Ketika logos dan pathos kadang tidak terpenuhi dengan baik, misalnya karena pembicara tidak bisa mengimplementasikan strategi public speaking yang efisien, pesan persuasif masih bisa tersampaikan karena orang yang berbicara dianggap memiliki kredibilitas (Scarantino, 2008). Perlu dicatat bahwa 'memiliki kredibilitas' di sini tidak secara otomatis berarti 'benar-benar memiliki kapasitas/keahlian', karena kredibilitas bisa disematkan oleh pendukung yang memiliki ketertarikan politis atau kekaguman subjektif (membentuk relasi fans dan fandom). Meskipun audiens mengalami kebosanan (berarti pathos pembicara tidak berhasil beresonansi dengan mereka) atau tidak berhasil memahami koherensi logika yang disampaikan (menunjukkan adanya permasalahan logos), jika yang berbicara adalah orang yang dianggap memiliki kredibilitas dan karakter, maka audiens cenderung bisa menerima pesannya. Hal ini menjelaskan mengapa beberapa figur publik sering menyampaikan hal yang terkesan tidak masuk akal dan kontroversial secara kognitif, tetapi ia masih memiliki pendukung yang menyetujui pendapatnya. Atau sebaliknya, pembicara yang memiliki kapasitas logos yang kuat dan ahli dalam menggunakan strategi pathos, tetap mengalami penolakan dari audiens karena ia dipandang tidak memiliki kredibilitas untuk membicarakan hal tersebut.

\section{Komunikasi Performatif dalam Politik Indonesia}

Praktek kehidupan berdemokrasi yang sehat memberikan ruang bagi berbagai perspektif yang berkompetisi. Karena kebebasan untuk mencari informasi, berkomunikasi dan berpendapat dijamin dalam demokrasi, adanya perbedaan perspektif menjadi tidak terelakkan. Pandangan-pandangan yang berbeda ini berinteraksi dalam bentuk dialog dan debat, baik yang bersifat formal (berlangsung dalam sebuah struktur dan ruang tertentu) atau informal (terjadi secara santai dan bagian dari dialektika kehidupan sehari hari). Seringkali keputusankeputusan penting dalam bermasyarakat dicapai melalui sebuah perdebatan, yang diwadahi di ruang-ruang politik milik publik.

Dalam bernegara, aspek politis tidak bisa dilepaskan dari kehidupan sehari-hari. Terlebih dalam masyarakat yang majemuk di mana setiap kelompok memiliki aspirasinya masing-masing yang ingin dipertahankan dan diprioritaskan. Public speaking menjadi instrumen yang krusial bagi politisi untuk memobilisasi konstituen dan pendukung mereka ke arah tertentu, misalnya mendukung atau menolak sebuah ide (Baccarani \& Bonfanti, (2015); Wrobel, 2015). Menurut Baccarani dan Bonfanti (2015), efektivitas public speaking para politisi ini akan tergantung pada kapasitas pembicara dalam mengelola cara berkomunikasi verbal dan non-verbal. Wrobel (2015) berargumen bahwa politisi harus mampu memastikan sinkronisasi ide dengan pemilihan kosa kata yang digunakan untuk mengekspresikan ide tersebut. Jika kedua dimensi tersebut bisa dipenuhi, audiens cenderung bisa memahami pesan yang disampaikan lewat pidato.

Dalam konteks rangkaian pemilihan presiden di Indonesia, terdapat dua situasi di mana calon presiden berpidato untuk menarik simpati dan dukungan dari publik: kampanye terbuka (rally) dan debat capres. Kedua kegiatan ini memiliki perbedaan karakteristik yang cukup kuat, utamanya dari segi pengkodean pesan. 
Kampanye terbuka bertujuan untuk mempromosikan dan mensosialisasikan seorang calon presiden. Massa dalam jumlah besar akan berkumpul untuk menonton dan mendengarkan pidato calon presiden, dan kegiatan ini merupakan rangkaian dari usaha komunikasi strategis yang integral dengan metode lainnya, seperti beriklan di media massa dan media sosial. Salah satu strategi yang awam digunakan untuk menarik atensi publik dalam politik adalah melibatkan sosok yang dikenal publik secara luas seperti artis dan selebriti dalam berbagai kegiatan kampanye, termasuk kampanye terbuka. Menurut Martana dan Andriana (2018), keberadaan para selebritis dianggap instrumental dalam usaha promosi aspirasi politis karena mereka memiliki popularitas yang tinggi dan pendukung yang loyal. Para selebritis juga terlibat secara intens di dalam rangkaian kegiatan kampanye terbuka, misalnya untuk memberikan semangat dan hiburan (Martana \& Andriana, 2018). Keseluruhan elemenelemen yang terdapat dalam kampanye terbuka dirancang untuk mengirimkan pesan-pesan persuasif yang menekankan pada keunggulan program milik diri sendiri serta aspek negatif dari kompetitor politiknya.

Merujuk pada tipologi karakter calon pemilih di Indonesia, publik tidak bisa dipetakan secara hitam-putih semata, tetapi sebagai spektrum. Ada kelompok yang sudah menentukan pilihan politiknya dengan mendukung satu calon presiden dan menolak kandidat lawannya, tetapi juga terdapat kelompok masyarakat yang belum menentukan pilihan. Kelompok ini masih memiliki keraguan kepada kedua calon presiden sehingga memerlukan informasi cukup dari kedua pihak sebelum menentukan pilihan. Adanya debat capres yang dilaksanakan secara sistematis dan dapat ditonton secara langsung, sebagai bagian dari rangkaian pemilu, bisa membantu publik memahami calon presiden mereka dengan lebih baik.

Studi mengenai analisis terhadap praktek public speaking yang dilakukan oleh politisi di Indonesia terbilang masih jarang. Salah satunya dilakukan oleh Sidabutar (2014) yang melakukan interpretasi pemaknaan atas pidato Aburizal Bakrie saat ia masuk ke dalam bursa bakal calon presiden Indonesia tahun 2014. Sidabutar (2014) menemukan bahwa Bakrie secara strategis mengatur penggunaan kata-kata dalam pidatonya untuk membentuk citra tertentu. Misalnya, Bakrie ingin dipandang sebagai pemimpin yang berorientasi masa depan dan dekat dengan berbagai kalangan di Indonesia. Bakrie juga menekankan keahlian dirinya di bidang ekonomi (Sidabutar, 2014). Sudut pandang yang dilakukan oleh Sidabutar (2014) terhadap pidato Bakrie sesungguhnya menunjukkan adanya pengaruh perspektif retorika persuasif Aristoteles (Wrobel, 2015; Varpio, 2018), yang juga digunakan di dalam studi ini. Penekanan pada 'penggunaan kata-kata untuk membentuk citra' merupakan manifestasi dari strategi ethos dan pathos, sementara usaha menunjukkan keahlian ekonomi merujuk pada aspek logos dari pidato tersebut. Sidabutar (2014) juga berargumen bahwa praktek public speaking sering digunakan oleh para politisi di Indonesia untuk menarik perhatian massa serta mengkonstruksi citra tertentu untuk mencapai tujuan politik praktis.

Wrobel (2015) mengkritik praktek public speaking yang dilakukan oleh para politisi secara umum. Menurutnya, ada kecenderungan bahwa politisi cenderung bergantung pada strategi pathos dibandingkan logos maupun ethos, yang ditunjukkan dari penghindaran mereka untuk menggunakan bahasa ilmiah dan 'kompleks' karena dianggap kurang populer sehingga mengurangi daya tarik di masyarakat umum. Hal ini awam ditemui di kampanye politik di Indonesia, di mana tokoh politik menekankan penggunaan retorika seperti 'mensejahterakan rakyat', 'menurunkan harga sembako' atau 'mengembalikan kedaulatan pangan' tanpa berusaha untuk menjelaskan langkahlangkahnya. Publik dianggap menyukai tagline politis yang dramatis, dan tidak mau repot untuk mengkritisi pesan sebelum 
menerimanya. Menurut Wrobel (2015), proses komunikasi politik idealnya berlangsung untuk berbicara dengan masyarakat luas, dan itu termasuk mereka yang 'sangat rasional seperti akademisi' maupun kelompok akar rumput yang tidak familiar dengan istilah-istilah kompleks. Audiens harus difasilitasi untuk bisa memahami ide-ide kompleks melalui pilihan kosakata pembicara (Wrobel, 2015). Artinya, para politisi harus memiliki strategi untuk menyampaikan klaim yang realistis dan bisa dipahami semua lapisan masyarakat di saat yang bersamaan.

\section{PEMBAHASAN}

Aspek pertama yang dianalisis dalam studi ini adalah ethos, yang mencakup usaha Joko Widodo dan Prabowo Subianto, sebagai calon presiden yang akan menyampaikan pidato, untuk membangun citra atas karakter mereka di panggung perdebatan. Perwujudan strategi ethos yang dominan dalam kegiatan tersebut adalah

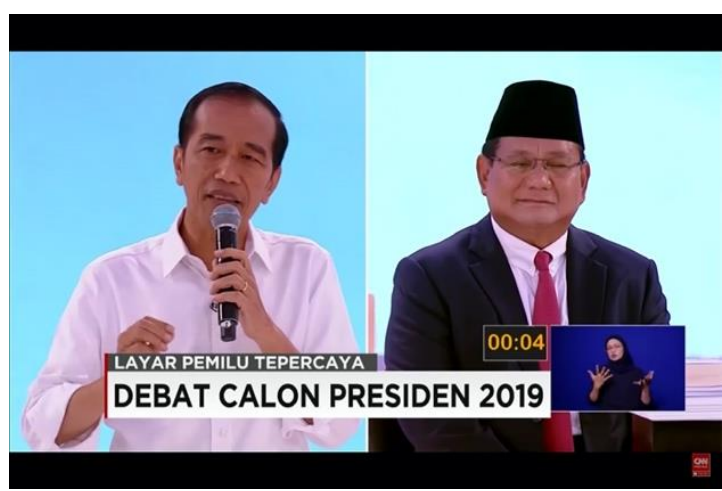

pakaian dan penampilan visual.

Gambar 1: Calon presiden Indonesia dalam Pemilihan Presiden 2019. Kiri: Joko Widodo, yang juga merupakan petahana. Kanan: Prabowo Subianto. Sumber:

https://www.youtube.com/watch? $v=C k 4 g J y O 4 G M c$

Penentuan pakaian yang digunakan merupakan bagian dari pengelolaan kesan (impression management) dalam panggung politik (Lampe, 2010), dan terkait langsung dengan usaha pembentukan karakter sesuai dengan perspektif ethos (Scarantino, 2008). Prabowo hadir di panggung dalam setelan formal dan dasi merah (Renaldi \& Shelton, 2019) untuk menandakan rasa hormatnya terhadap formalitas forum serta memperkuat identitasnya sebagai mantan jenderal militer, yang seringkali berkorelasi dengan karakter disiplin dan resmi. Terlebih lagi, presiden yang berjenis kelamin llaki-laki di Indonesia umumnya tampil dengan jas, dasi merah dan peci sehingga pilihan pakaian Prabowo mencerminkan aspirasinya untuk mengemban jabatan tersebut. Sebaliknya, strategi pemilihan pakaian Joko menunjukkan pesan yang sangat jelas untuk berkompetisi dengan Prabowo. Alih-alih tampil formal juga, Renaldi dan Shelton (2019) mencatat bahwa Joko menggunakan kemeja putih dipadukan dengan celana panjang hitam dan sepatu kasual. Tidak hanya itu, Joko juga menggulung lengan kemejanya sebatas siku. Perpaduan pakaian ini menunjukkan bahwa Joko sedang berusaha mengurangi jarak kekuasaan (power distance) antara ia dengan konstituen, dengan ruangan debat, dan dengan lawannya. Dengan menekankan citra santainya, Joko mengkomunikasikan dua pesan secara ethos: 1) bahwa ia ingin membangun dan mempertahankan kedekatan dengan audiensnya, dan 2) bahwa ia memiliki status sosial yang lebih tinggi dibanding lawannya. Joko hadir di kegiatan Debat Capres sebagai petahana, dan dengan menggunakan pakaian yang kurang formal, ia menunjukkan bahwa ia memiliki kuasa yang lebih tinggi di dalam forum sehingga lawannya harus tampil formal untuk berada di tingkat yang sama dengan dirinya.

Salah satu demonstrasi pemanfaatan strategi ethos yang cukup menarik terjadi pada sesi tanya jawab, di mana para kandidat diminta untuk menyampaikan dan menanggapi pertanyaan dari satu sama lain. Joko bertanya, "Infrastruktur apa yang akan Bapak bangun untuk mendukung perkembangan unicorn Indonesia?", yang kemudian direspon Prabowo dengan "[Apa] yang Bapak maksud [dengan] unicorn? Maksudnya yang online-online itu, iya, 'kan?" (Renaldi \& Shelton, 2019). Dalam konteks pertanyaan ini, istilah 'unicorn' merujuk pada perusahaan rintisan teknologi (start up companies) yang memiliki valuasi di atas 1 milliar dollar Amerika. Berhubung generasi muda di Indonesia memiliki 
ketertarikan kuat terhadap perkembangan teknologi dan dunia start up, pertanyaan sederhana yang diajukan oleh petahana menunjukkan bahwa ia menggunakan ethos untuk menarik perhatian pemilih muda. Terlebih lagi, pertanyaan tersebut direspon dengan kebingungan Prabowo, yang kemudian mengalihkan pembicaraan ke tema pemberdayaan pertanian. Joko memahami adanya perbedaan pengetahuan dengan lawannya ini, dan mengeksploitasinya untuk memenuhi aspek ethos performanya pada perdebatan tersebut.

Dalam aspek logos, kedua kandidat berhasil menunjukkan kekayaan pengetahuan yang mereka miliki. Data yang digunakan relatif kuat, dan baik Joko maupun Prabowo mampu menunjukkan kapasitas mereka untuk menggunakan fakta dalam berargumen. Studi ini memang tidak melakukan analisis atas kualitas logika dan substansi yang disampaikan dalam debat, tetapi peneliti melihat adanya kekurangan para kandidat dalam menyampaikan pesan secara terstruktur. Menurut Varpio (2018), signposting (pemberian tanda untuk mengawali dan mengakhiri argumen) adalah salah satu aspek krusial dalam logos karena bisa membantu audiens untuk mengikuti alur logika pembicara. Jika kedua calon presiden menggunakan signposting dengan efisien, maka audiens bisa mengetahui ide yang akan disampaikan, kapan sebuah argumen berakhir dan memetakan struktur pesan dengan mudah.

Publik menaruh ekspektasi yang tinggi terhadap kualitas substansi pesan dan argumen para calon presiden dalam debat tersebut. Mereka menginginkan Joko dan Prabowo menyampaikan presentasi data dengan akurasi tinggi, jika tidak mutlak. Ekspektasi ini dicerminkan oleh keberadaan berbagai media massa yang memantau dan menerbitkan pemeriksaan fakta dan data yang disampaikan oleh kedua calon presiden dalam debat, misalnya artikel Debat Kedua Pilpres 2019: Periksa Klaim, Uji Kemampuan (Ahsan, 2019) yang diunggah oleh Tirto.id (www.tirto.id) dan microsite Cek Fakta Debat Capres Kedua 2019 (CNN Indonesia, 2019) yang ditayangkan oleh CNN Indonesia. Media luar negeri seperti $\mathrm{ABC}$ News dari Australia juga mengulas perdebatan tersebut, misalnya dalam berita Unicorns become an unexpected symbol of Indonesia's second presidential debate (Renaldi \& Shelton, 2019).

Mengingat bahwa Joko maupun Prabowo akan menjadi pemimpin pemerintahan nantinya, validitas data dalam debat yang ditonton publik secara langsung menjadi penting; seorang presiden sebaiknya tidak memiliki asosiasi dengan kecerobohan pengelolaan dan presentasi data. Meskipun demikian, Wróbel (2015) mengingatkan bahwa pidato politik yang terlalu mengandalkan data dapat menjadi kontraproduktif, karena para politisi ini sedang berkomunikasi dengan berbagai lapisan masyarakat yang tidak semuanya familiar dengan presentasi data murni.

Terlepas dari strategi kedua calon presiden untuk mempertahankan integritas fakta dan data yang dipresentasikan, usaha tersebut cenderung diiringi dengan pendekatan berbasis pathos ketika memungkinkan. Bentuk implementasi pathos umumnya tampak pada reaksi kandidat terhadap topik tertentu yang disampaikan dalam pidato, atau terhadap sisi personal lawannya. Sebagai contoh, seperti yang ditunjukkan pada Gambar 2, Joko mulanya memperhatikan Prabowo yang sedang berpidato namun kemudian mengalihkan pandangannya dengan cepat serta memutar bola matanya, sebagai tanda ketidaksetujuan. Gestur ini tidak melibatkan kata-kata yang disampaikan secara verbal, tetapi cukup kuat untuk mengirimkan pesan kepada pendukungnya. 

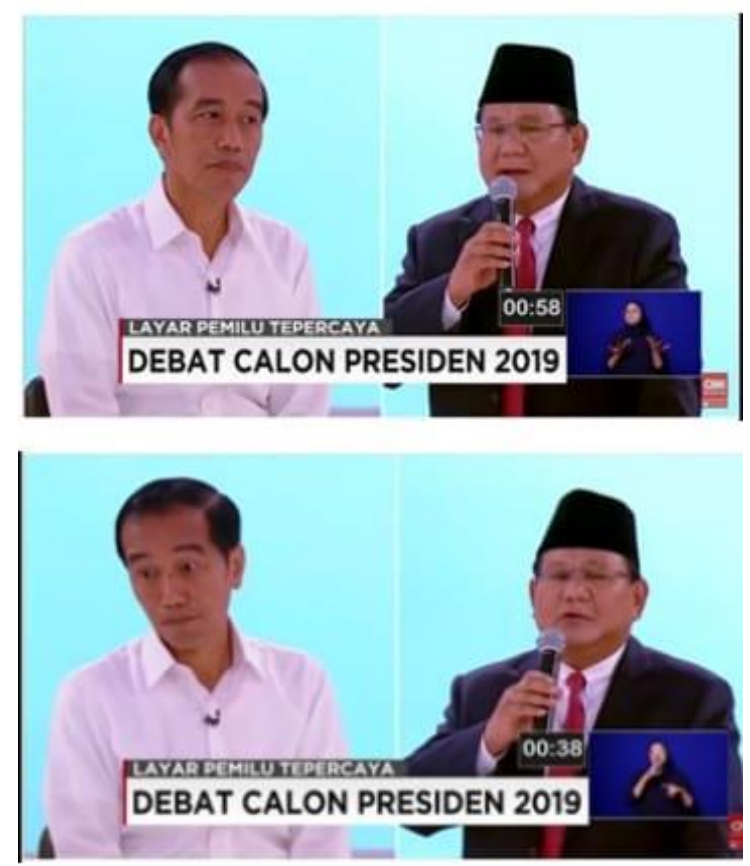

Gambar 2: Contoh strategi pathos oleh Joko Widodo. Atas: sebelum. Bawah: sesudah. Sumber: https://www.youtube.com/watch? $v=C k 4 g J y O 4 G M c$

Kedua calon presiden seringkali mendemonstrasikan strategi pathos seremonial (Wróbel, 2015) di mana mereka memberikan evaluasi atas performa lawannya dalam bentuk pujian atau kecaman. Prabowo memuji Joko sebanyak lima kali sepanjang perdebatan, sementara sebaliknya, Joko hanya memberikan pujian satu kali. Pilihan kata-kata yang mereka gunakan dalam berdebat juga cukup kontras, di mana Prabowo sering mengekspresikan hormat dan pengakuan atas lawannya sebelum memberikan kritik. Frase yang cenderung digunakan Prabowo adalah "...Saya menghargai kepemimpinan dan pemerintahannya, tetapi...". Kalimat ini tidak pernah digunakan Joko, tetapi ia seringkali mengawali argumennya dengan penekanan pada hubungan personal. Contohnya, Joko merujuk pada Prabowo dengan "sahabat saya, Bapak Prabowo Subianto,". Strategi pemilihan kata-kata yang spesifik ini menunjukkan adanya faktor pathos yang menentukan arah perdebatan dan pidato mereka.

\section{KESIMPULAN}

Debat kedua presiden Indonesia tahun 2019 adalah demonstrasi menarik dari komunikasi performatif politik yang berhasil memanfaatkan Prinsip Retorika Aristoteles. Kedua kandidat memanfaatkan kesempatan untuk berbicara di hadapan publik secara strategis dan unik, karena selain berdebat, mereka sesungguhnya sedang melakukan persuasi terhadap kelompok audiens yang berbeda.

Esai ini hanya melakukan analisis pada debat presiden kedua dalam rangkaian kampanye Pemilu 2019 di Indonesia. Temuan dari studi ini tidak dimaksudkan untuk menggeneralisir karakter kandidat presiden secara keseluruhan karena peneliti tidak menganalisis empat debat lainnya, maupun kesempatan lain di mana para calon presiden ini melakukan public speaking.

Salah satu prinsip dasar dari komunikasi massa adalah menyesuaikan pesan dan penyampaian pesan dengan karakter audiens serta tujuan berkomunikasi, sehingga terdapat peluang yang cukup besar bahwa calon presiden, maupun figur politik lainnya menunjukkan karakter dan strategi retorika persuasif yang berbeda di masingmasing kesempatan.

Ke depannya, studi ini dapat dikembangkan untuk mengevaluasi kinerja retorika tokoh lainnya, atau melihat respon konstituen terhadap aspek retorika persuasif pada pidato tokoh politik. 


\section{REFERENSI}

Ahsan, I. A. (2019). Debat Kedua Pilpres 2019: Periksa Klaim, Uji Kemampuan. Tirto.id. https://tirto.id/debat-kedua-pilpres2019-periksa-klaim-uji-kemampuan-dg8C

Aji, N., \& Dartanto, T. (2018). Behind the Jokowi's victory: Did economic voting matter in the 2014 Indonesian presidential election? Asia-Pacific Journal of Regional Science, 2(1), 115-138. https://doi.org/10.1007/s41685-018-0083-3

Baccarani, C., \& Bonfanti, A. (2015). Effective public speaking: A conceptual framework in the corporate-communication field. Corporate Communications: An International Journal, 20(3), 375-390. https://doi.org/10.1108/CCIJ-04-2014-0025

CNN Indonesia. (2019). CEK FAKTA DEBAT CAPRES KEDUA 2019. CNN Indonesia.

https:/www.cnnindonesia.com/laporanmen dalam/nasional/20190215/cekfakta-debatcapres-kedua-2019/index.php

Collins, L., \& Jisum, C. (2019). The role of linguistics studies on the political debate. Linguistics and Culture Review, 48-59. https://doi.org/10.37028/lingcure.v3n1.15

Lampe, I. (2010). Identitas Etnik dalam Komunikasi Politik. Jurnal Ilmu Komunikasi, 8(3), 299-313.

Leliana, I., \& Agusta, V. (2019). STRATEGI HUMAS KEMENTERIAN PERINDUSTRIAN DALAM MENGINFORMASIKAN LAYANAN PUBLIK MELALUI YOUTUBE. Jurnal Ilmu Komunikasi, 6(2), 10.

Martana, I. K., \& Andriana, D. (2018). Endorser Selebriti Pada Iklan Politik Sebagai Upaya Vote Getter Pada Pemilih Muda. Jurnal Ilmu Komunikasi, 1, 15.

Renaldi, E., \& Shelton, T. (2019). Unicorns become an unexpected symbol of Indonesia's second presidential debate. $A B C \quad N e w s$. https://www.abc.net.au/news/2019-02- 18/joko-widodo-indonesia-presidentialdebate-prabowo-subianto/10820310

Sandra, L. J. (2013). POLITICAL BRANDING JOKOWI SELAMA MASA KAMPANYE PEMILU GUBERNUR DKI JAKARTA 2012 DI MEDIA SOSIAL TWITTER. 12.

Scarantino, L. M. (2008). Persuasion, Rhetoric and Authority. Diogenes, 55(1), 22-36.

https://doi.org/10.1177/0392192107087915

Shibghotulloh, D. (2019). Rivalitas Purnawirawan Jenderal Militer dalam Pemilihan Presiden 2019. Politicon : Jurnal Ilmu Politik, 1(2), 158-175. https://doi.org/10.15575/politicon.v1i2.596 3

Sidabutar, S. C. (2014). PENCITRAAN POLITIK ABURIZAL BAKRIE DALAM TEKS PIDATO MENDAKI SEMERU DAN TEKS PIDATO INDONESIA DALAM MIMPI SAYA. 2, 11.

Simarmata, S. (2017). Paralelisme Politik Media dalam Pemberitaan Pemilu 2014 di Indonesia. Jurnal Ilmu Komunikasi, 14(2), 20 .

Varpio, L. (2018). Using rhetorical appeals to credibility, logic, and emotions to increase your persuasiveness. Perspectives on Medical Education, 7(3), 207-210. https://doi.org/10.1007/s40037-018-0420-2

Wróbel, S. (2015). "Logos, Ethos, Pathos". Classical Rhetoric Revisited. Polish Sociological Review, 191, 401-421.

\section{BIODATA PENULIS}

Meganusa Prayudi Ludvianto mendapatkan gelar pascasarjananya dari School of Communication and Arts, Faculty of Humanities and Social Sciences, The University of Queensland. Sebelumnya ia memperoleh gelar sarjana dari Jurusan Ilmu Komunikasi, FISIPOL UGM. Fokus penelitiannya mencakup komunikasi partisipatif dan ICT4D. 
Wenny Noor Arifani mendapatkan gelar sarjananya dari Jurusan Ilmu Komunikasi, FISIPOL UGM. Minat penelitiannya berada di area fandom, brand community dan komunikasi untuk perubahan sos 